\section{Multidisciplinary \\ SCIENTIFIC JOURNAL OF \\ MARITIME RESEARCH}

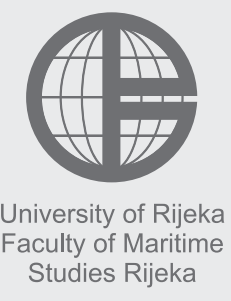

Multidisciplinarni

znanstveni časopis

POMORSTVO

\title{
The Role of logistics in the exploitation of crude oil from the seabed
}

\author{
Jelena Žanić Mikuličić ${ }^{1}$, Čedomir Dundović ${ }^{2}$ \\ ${ }^{1}$ The University of Split, Faculty of Maritime Studies, Ruđera Boškovića 37, 21000 Split, Croatia, e-mail: jzanic@pfst.hr \\ ${ }^{2}$ The University of Rijeka, Faculty of Maritime Studies Rijeka, Studentska 2, 51000 Rijeka, Croatia, e-mail: dundovic@pfri.hr
}

\begin{abstract}
The process of oil and natural gas extraction is one of the most technically complex processes in the modern industry. Offshore platforms, special drill ships and mobile oil plants are the only ways of extracting oil from the seabed.

The paper will highlight the role of oil in the maritime economy and the importance of the logistic chain on the example of Norway. It will provide a theoretical overview of the role of oil exploration through the logistic system, oil stock analysis, export and import analysis of oil quantities through world regions by the model and calculation of direct growth rates of selected variables. In this paper, methods of analysis and synthesis, inductive and deductive methods, comparative methods and growth matrix methods have been used.
\end{abstract}

\author{
A RT I C L E I N FO \\ Preliminary communication \\ Received 1 December 2017 \\ Accepted 19 December 2017 \\ Key words: \\ Logistics \\ Oil drill \\ Offshore platforms \\ Logistic system \\ The model of direct growth rates
}

\section{Introduction}

Oil covers over $40 \%$ of the world's energy needs. It appeared more than 300 million years ago and is today an indispensable fuel in industry and other human activities. It is used in the manufacture of chemicals, paints, plastics and electronic components. Almost 56\% of all proven oil reserves are located in the Middle East region. The Middle East, except that it has the largest stock of crude oil, is the world's largest oil producer and exporter. Saudi Arabia is the leading country of the Middle East and, as the world's largest oil producer in 2006, it produced 10.66 million barrels of oil per day or $13 \%$ of the total oil produced in that year. The strong development of the economy of the third world countries (China, South Korea, Indochina and India) led to an increasing demand for oil, as well as the growth of the Russian economy which also greatly influenced the crude oil market in the world. A steady rise in demand, as the most important initiator of the oil price increase, is recorded by the US Federal Reserves, as well as by the OECD countries.

\section{The term logistic activities}

Logistics as a science represents multidisciplinary and interdisciplinary knowledge that studies and applies the process of planning, organizing, managing and controlling flows of materials, persons, energy and information in systems [3]. It tries to find out methods of optimizing these flows in order to achieve the economic effect (profit). Logistics uses features provided by modern computer technology and is able to analyse complex processes in a variety of systems in detail [4]. It can forecast the development of these processes and systems, as well as their cost, needs and capabilities and optimize various processes and systems from a financial and other points of view. In order to be as good and safe as possible for sustainable development, the exploration of the sea and the seabed, as well as of the mineral resources - oil, gas, coal, sand, ore, salt, copper and other valuable resources - must be designed and developed through logistic activities.

\subsection{Logistics in maritime economy}

The specificity of logistics of the maritime economy is related to the complex logistic phenomena of the production branches of the maritime economy (shipbuilding, fisheries and exploitation of maritime and marine mineral resources), as well as to numerous and complex logistic phenomena of the service branch of the submarine economy (sea shipping, seaport, coastal tourism and various 


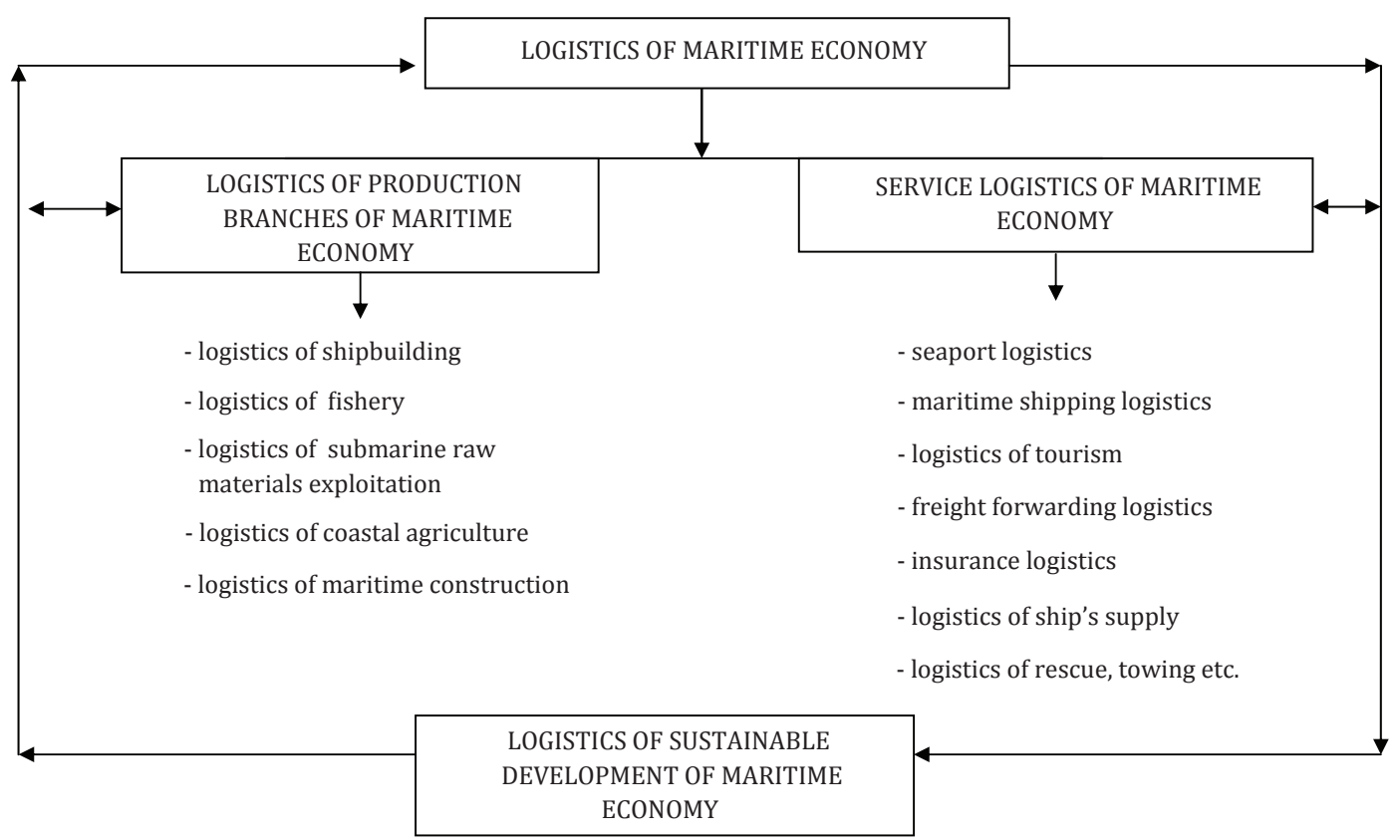

Figure 1 Subsystems of the Maritime Economy Logistics System

Source: http://www.fsb.unizg.hr/atlantis/upload/newsboard, $18^{\text {th }}$ June 2016

maritime services - shipping agencies, freight forwarders, ship supply) [8]. The maritime economy is a narrower term than the maritime one, but broader than maritime transport and sea shipping [2]. The complex, dynamic and stochastic logistic system of the maritime economy represents a specific part of the logistic system, which consists of two fundamental logistic subsystems: logistics of the manufacturing sector of the maritime economy and the logistics of service sectors of the maritime economy. Subsystems, as well as the logistic system, have a strong support of the logistic subsystem of the sustainable development of the maritime economy [7].

Every industry represents a unique supply chain challenge, but none is as complex as oil and gas. Exploitation of oil from the seabed and its transport require a special logistic chain that implies adequate equipment, strict regulatory compliance, and extensive safety procedures [1]. It often has more operating modes and includes the following ones: offshore plants, oil platform supply and hazardous raw material transport.

\subsection{The role of logistic activities in the exploitation of oil from the seabed}

Logistics of oil exploitation from the seabed is reflected in the exploitation of sea and submarine resources at acceptable market prices. Investments in exploration and exploitation of the seabed can be profitable and unprofitable for the company, so the task of the logistics is to find ways of reducing the cost of exploitation and, on the other hand, make production more competitive on the market $[5,6]$. It is important to develop integrated logistic solu- tions for the exploitation of oil, which start with setting up the plant, drilling, exploitation, production and transport.

The systematic use of offshore plants includes the supply of ships by platform (PSV), transport of waste in containers and transport of oil from tankers to ports. Heavy weather conditions in seas and/or oceans increase the number of possible disruptions affecting individual segments of logistics. The World Agencies for Planning has made a strategic plan for logistics in oil exploitation by 2042. The goal is to determine the required number of vessels for supplying the platform and to compare different options of the outgoing logistic network after the exploitation of oil from the seabed [10].

The aforementioned logistic system raises the following questions: How many suppliers are needed? Is there a need to rent a floating base (FPSO) to store the oil? What size of the land base is needed to be built? The logistic system carefully examines every step because the price of each mistake is very high. Buying unnecessary vessels for the supply of the platform can result in a multi-millionaire loss and lack of tankers can lead to emergencies on the platform, such as oil spills [12]. In order to avoid any mistake, a simulation model has been developed so that strategic planning could be as accurate as possible. The exploitation of oil from very deep seabed requires a special logistic approach. In the Gulf of Mexico, there are about 3400 drill holes with depths of over 1500 metres. Although oil exploitation at these depths has not been technologically and economically feasible for many years, nowadays more and more companies are investing in this area. The major companies operating in this sector are Halliburton, Diamond Offshore, Trans-Ocean, Geo-Services and Schlumberger. In this area, the market of 


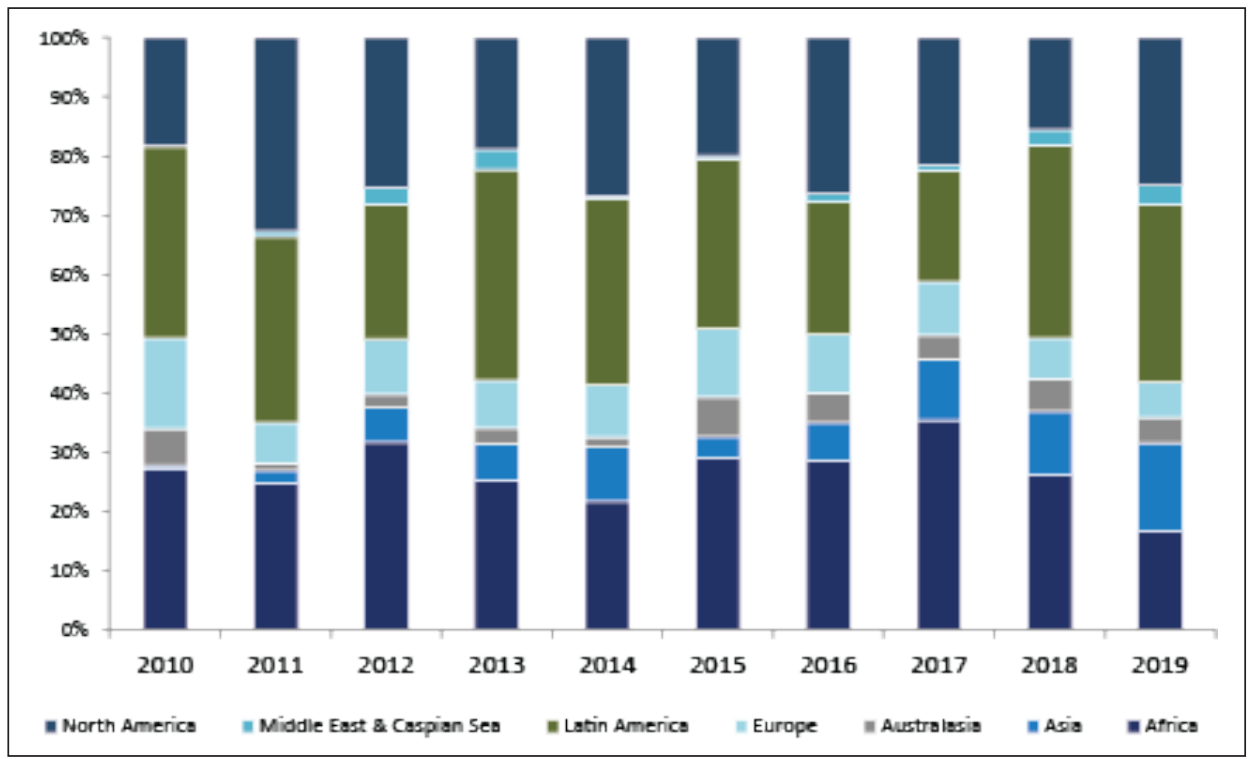

Figure 2 Exploitation of Oil from Seabed on Continents in the Period from 2010 to 2019

Source: https://www.infield.com/media-centre/articles/2015/global-subsea-market-review, $7^{\text {th }}$ July 2017

oil in deep seabed is growing again after the catastrophe in 2010 and the total expenditure of around $\$ 35$ billion.

The exploitation of oil from the seabed will have a positive growth in 2019. During the 2015 and 2019 period, the increase will be $16 \%$ as compared to the previous fiveyear period. It is expected that giants such as Brazil, the Gulf of Mexico and Western Africa will continue to demand deep-sea oil exploitation ( $=>1500 \mathrm{~m}$ ) over the long term and it is predicted that the demand will be $51 \%$ throughout the five-year period $[9,10]$.

The world oil production grew 0.4 million barrels per day in 2016. Production of oil in the Middle East led by Iran, Iraq and Saudi Arabia increased 1.7 million b/d.
This was preceded by a fall in North, Central and South America, Africa and Asia. The average growth in the global oil consumption is 1.6 million $b / d$, which is above the 10 -year average of 1 million b/d. China (400,000 b/d) and India $(330,000 \mathrm{~b} / \mathrm{d})$ have contributed most to the consumption growth [11].

\section{Exploitation of oil from the seabed on the example of Norway}

Oil exploitation from the seabed is the strongest industrial branch in Norway which brings the state 53 billion euros per year. According to the Norwegian Ministry of Finance

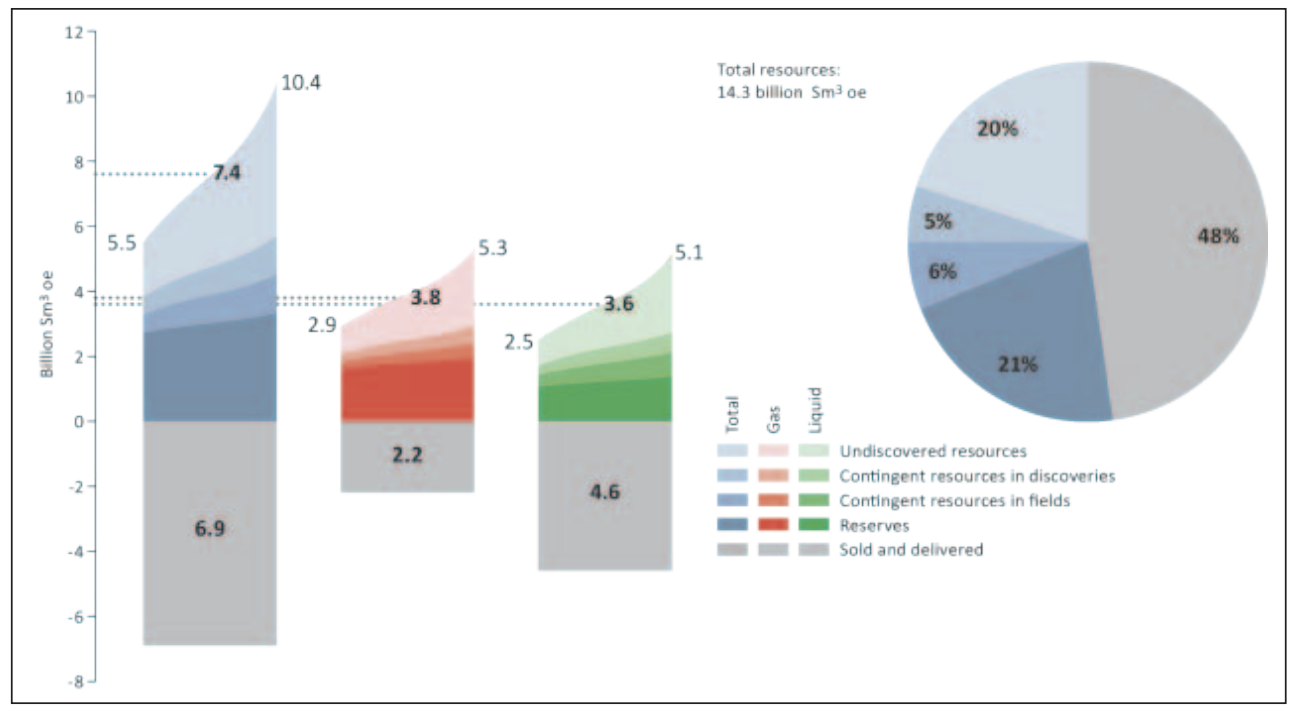

Figure 3 Oil Reserves of Norway on $31^{\text {st }}$ December 2016 
data for 2015, 27.1\% of the total state budget revenue comes from the oil and gas sectors. In the Norwegian Gross Domestic Product, the oil sector participates with $18.6 \%$ [12]. Nearly $30 \%$ of the total investment in the country is just in the oil and gas industry and its related sectors and hydrocarbons make $46 \%$ of all Norwegian export products.

The Norwegian companies are constantly monitoring the development of new technologies for the construction, servicing and supply of increasingly numerous oil platforms, relying on the experience and the established logistic system. Thanks to the good implementation of logistics, they turned to a new branch of the industry adapting their offer to the technological requirements of oil companies and thus pushing cheaper Asian competitors. They also called for the right to exploit the seabed treasures of Antarctica, i.e. subsoil resources and 60 million barrels of proven oil reserves that would be sufficient for 40 years. Experts predict that, up to the year 2018 , even more than $12 \%$ of oil will be exploited at a depth deeper than 200 metres, compared to only $2 \%$ in 2001 . According to today's estimates, global oil production will probably begin to fall in 2035 .

The main assessment of the Norwegian Oil Department for the total proven and undiscovered oil resources amounst to about 14.3 billion $\mathrm{m}^{3}$. It is assumed that, by 2010, 7.4 billion $\mathrm{m}^{3}$ will be produced. The undiscovered resources amount to 2.9 billion $\mathrm{m}^{3}$. They make up $39 \%$ of the total remaining funds.

The report for the North Sea shows that, last year. 160 million $\mathrm{m}^{3}$ was delivered to the market from this part of the sea. At the same time, gross reserves amounted to 59 million $\mathrm{m}^{3}$. This means that the remaining reserves in the North Sea decreased by 101 million $\mathrm{m}^{3}$ in 2016. Potential field resources were increased by 42 million $\mathrm{m}^{3}$ in 2016, based on a high-quality logistics that gradually introduced new projects for better recovery. Contingent resources were reduced by 30 million $\mathrm{m}^{3}$ as compared to the last

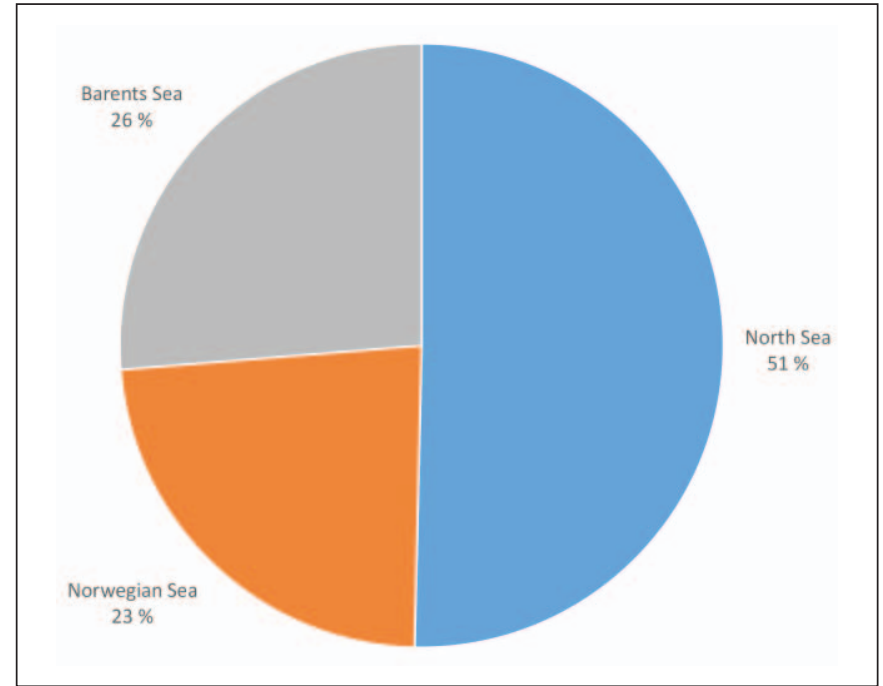

Figure 4 Oil Reserves of Norway as to Oil Fields in Different Seas on $31^{\text {st }}$ December 2016

Source: http://www.npd.no/en/Topics/Resource-accounts-and-analysis/3 $/ 3^{\text {th }}$ uly 2017

year [12]. The discovery of fourteen new areas (sources) in the North Sea in 2016 brought 50 million $\mathrm{m}^{3}$ of oil.

The report for the Norwegian Sea shows that 61 million $\mathrm{m}^{3}$ have been delivered from this part of the sea over the past year. At the same time, gross reserves are subtracted, which implies a reduction of the remaining reserves in the Norwegian Sea by 10 million $\mathrm{m}^{3}$.

The Barents Sea report shows that 10 million $\mathrm{m}^{3}$ have been delivered from this part of the oil field over the past year. At the same time, gross reserves increased by 2 million $\mathrm{m}^{3}$, which implies a reduction of the remaining reserves of 8 million $\mathrm{m}^{3}$. Compared to the previous year, the estimation of new sources will increase by 19 million $\mathrm{m}^{3}$.

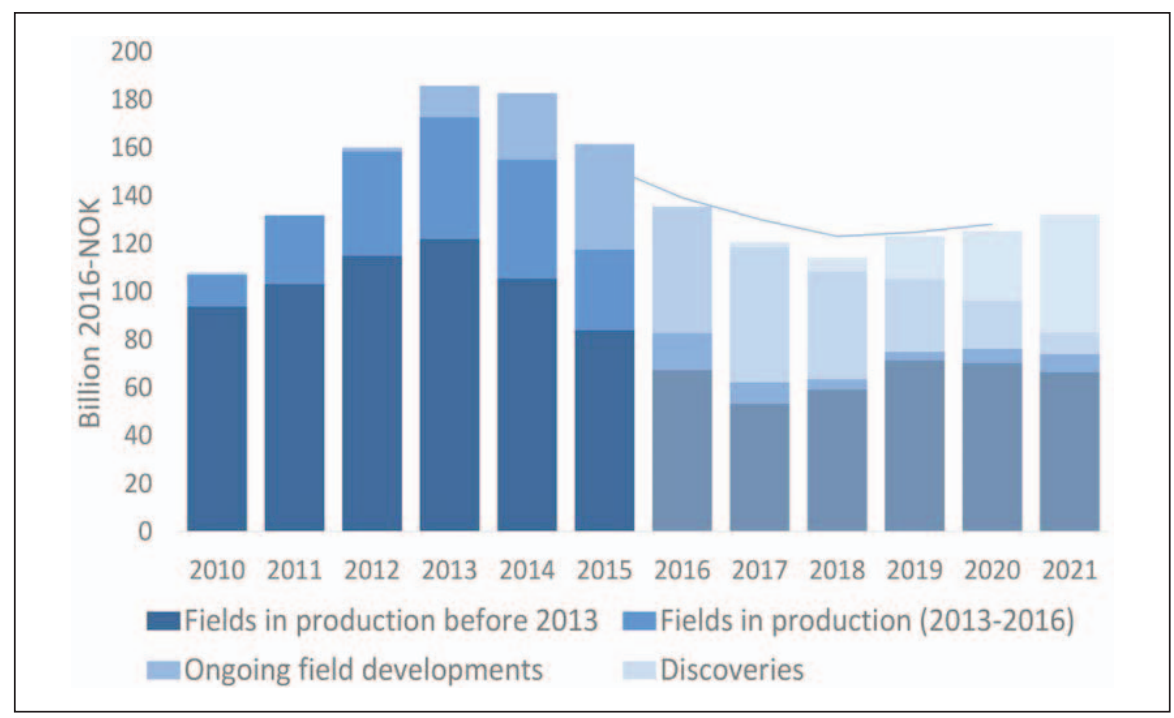

Figure 5 Assessments of Oil Deposits in the Period from 2010 to 2020 
There are currently seven Norwegian development projects of $\$ 27.3$ billion worth. After several years of research activity, 18 oil discoveries were realized, one more than in 2015. Fourteen were found in the North Sea and 2 in Norway and the Barents Sea. The aforementioned discoveries are minor but mostly located near the existing infrastructure [15]. Within the definition of logistics, this would mean that they can quickly become profitable if they are related to operational areas and facilities. A good and dynamic logistic system has enabled the economic growth of the Norwegian offshore economy and is a strong supporter of the development of entrepreneurial ideas and initiatives.

\section{Analysis of the current state of oil import and export through the world regions}

According to the OPEC, supplies are considered to be sufficient for the next 50 years. Production will not be able to monitor the level of consumption, which is due to the shortage of production facilities and crude oil supplies from the seabed [13]. Within the existing traffic conditions, 38 million barrels of oil per day are consumed. The industry consumes 22 , households and agriculture 10 and the rest (about 13 million barrels of oil) is consumed in energy production.

Table 1 Oil Export and Import in Millions of Tons through the World Regions in 2014 and 2016

\begin{tabular}{|l|c|c|}
\hline \multicolumn{1}{|c|}{ Millions of tons } & $\begin{array}{c}\text { Oil 2014 } \\
\text { Export-import }\end{array}$ & $\begin{array}{c}\text { Oil 2016 } \\
\text { Export-import }\end{array}$ \\
\hline The United States & 383,5 & 417,7 \\
\hline Europe & 450,7 & 517 \\
\hline Russia & 242,7 & 274,8 \\
\hline The Middle East & 862,9 & 1,006 \\
\hline Africa & 237,6 & 245,2 \\
\hline Australia and Asia & 1026 & 1124 \\
\hline
\end{tabular}

Source: Authors

The world oil production grew by only 0.4 million tons in 2016, which is the slowest growth than in 2013. Oil production in the Middle East grew by 1.7 million tons and its producers are the countries of Iran, Iraq and Saudi Arabia. This has largely compensated for the decline in North America, Africa, Asia and South and Central America [13, $14]$. The average growth in the global oil consumption is 1.6 million tons, which is above the 10 year average.

\section{The model of world oil transport from 2014 to 2018}

The design of the model of world oil transport from 2014 to 2018 will be accessed on the basis of certain model variables as follows:

1. the United States,

2. Europe,

3. Russia,
4. the Middle East,

5. Africa,

6. Australia and Asia.

Based on the previously elaborated basic research and the assessment of growth variables (on a scale of 1 to 100), Table 2 follows:

Table 2 Value of Variables of the World Oil Transport from 2014 to 2018

\begin{tabular}{|c|c|c|c|c|c|}
\hline \multirow{2}{*}{\multicolumn{2}{|c|}{$\begin{array}{l}\text { Value of variables of } \\
\text { the world oil transport } \\
\text { from } 2014 \text { to } 2018\end{array}$}} & \multicolumn{3}{|c|}{ Input $y$} & \multirow{3}{*}{$\begin{array}{c}\text { Growth } \\
2014 / 18 \\
7\end{array}$} \\
\hline & & \multirow{2}{*}{$\frac{2014}{72}$} & \multirow{2}{*}{$\frac{2016}{75}$} & \multirow{2}{*}{$\begin{array}{c}2018 \\
79\end{array}$} & \\
\hline 1. & The United States & & & & \\
\hline 2. & Europe & 75 & 80 & 85 & 10 \\
\hline 3. & Russia & 77 & 79 & 81 & 4 \\
\hline 4. & The Middle East & 70 & 80 & 85 & 15 \\
\hline 5. & Africa & 60 & 65 & 67 & 7 \\
\hline 6. & Australia and Asia & 90 & 93 & 95 & 5 \\
\hline
\end{tabular}

Source: Authors

From the above-mentioned data, the quantification of the variables of the model of world oil transport from 2014 to 2018 on the basis of the data from the previous tables follows. The vector of the reciprocal model values is:

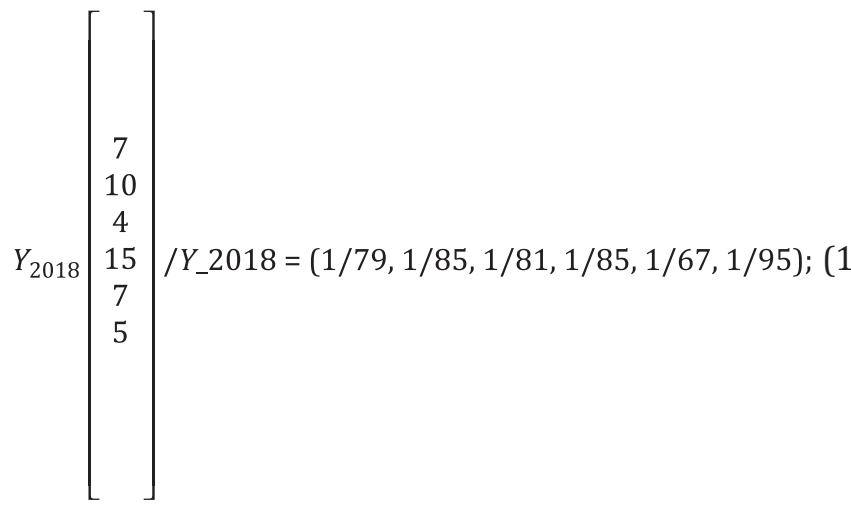

A multiplicity of external vectors determines the growth matrix of the world oil transport model in relation to current values.

The matrix of the model will grow from 2014 to 2018.

$R_{2018}\left[\begin{array}{cccccc}\frac{7}{79} & \frac{7}{85} & \frac{7}{81} & \frac{7}{85} & \frac{7}{67} & \frac{75}{95} \\ \frac{10}{79} & \frac{10}{85} & \frac{10}{81} & \frac{10}{85} & \frac{10}{67} & \frac{10}{95} \\ \frac{4}{79} & \frac{4}{85} & \frac{4}{81} & \frac{4}{85} & \frac{4}{67} & \frac{45}{95} \\ \frac{15}{79} & \frac{15}{85} & \frac{15}{81} & \frac{15}{85} & \frac{15}{67} & \frac{15}{95} \\ \frac{7}{79} & \frac{75}{85} & \frac{7}{81} & \frac{7}{85} & \frac{7}{67} & \frac{75}{95} \\ \frac{5}{79} & \frac{5}{85} & \frac{5}{81} & \frac{5}{85} & \frac{57}{67} & \frac{55}{95}\end{array}\right]$




$$
R_{2018}\left[\begin{array}{llllll}
0,089 & 0,082 & 0,086 & 0,082 & 0,104 & 0,074 \\
0,127 & 0,118 & 0,123 & 0,118 & 0,149 & 0,105 \\
0,051 & 0,047 & 0,049 & 0,047 & 0,060 & 0,042 \\
0,190 & 0,176 & 0,185 & 0,176 & 0,224 & 0,158 \\
0,089 & 0,082 & 0,086 & 0,082 & 0,104 & 0,074 \\
0,063 & 0,059 & 0,062 & 0,059 & 0,075 & 0,053
\end{array}\right]
$$

Table 3 Direct Growth Rates of the World Oil Transport Model from 2014 to 2018

\begin{tabular}{|c|c|c|c|c|c|c|}
\hline $\begin{array}{c}\text { Model } \\
\text { variables }\end{array}$ & $\mathbf{1}$ & $\mathbf{2}$ & $\mathbf{3}$ & $\mathbf{4}$ & $\mathbf{5}$ & $\mathbf{6}$ \\
\hline 1 & $\mathbf{8 , 9}$ & 8,2 & 8,6 & 8,2 & 10,4 & 7,4 \\
\hline 2 & 12,5 & $\mathbf{1 1 , 8}$ & 12,3 & 11,8 & 14,9 & 10,5 \\
\hline 3 & 5,1 & 4,7 & $\mathbf{4 , 9}$ & 4,7 & 6 & 4,2 \\
\hline 4 & 19 & 17,6 & 18,5 & $\mathbf{1 7 , 6}$ & 22,4 & 15,8 \\
\hline 5 & 8,9 & 8,2 & 8,6 & 8,2 & $\mathbf{1 0 , 4}$ & 7,4 \\
\hline 6 & 6,3 & 5,9 & 6,2 & 5,9 & 7,5 & $\mathbf{5 , 3}$ \\
\hline
\end{tabular}

Source: Authors

The study has presented direct growth rates (diagonal). In 2018, the largest direct growth rate in the world oil transport will have the Middle East variable with $17.6 \%$, followed by Europe with $11.8 \%$, Russia with $4.9 \%$ and Australia and Asia with 5.3\%.

By comparing the growth of the model variables (Table 2 ) and the direct growth rates of the model (Table 3), it can be seen that the synergistic relationship of variables affects the real state of the future.

\section{Conclusion}

Based on the above mentioned, it is obvious that maritime economy logistics is one of the fundamental factors of the efficiency of the maritime-economic system. Logistic activities enrich, concretize, integrate and compete with the structure of the maritime onshore or offshore maritime system. The aim of logistic activities in the context of petroleum companies is to achieve the best possible effects at a given moment, to reduce all possible risks that can arise with an ecological disaster and not to cause great economic and financial damage. To avoid this, it is important to develop a systematic approach to logistics. The paper gives Norway as an example of a country with such an approach that prevents automation and explores the limits of applicability and research techniques.

Other oil richest areas on Earth are only being explored and established and their maritime economy is unable to accelerate development and to contribute to economic development without a direct logistic system. The concept and strategy of such logistic sciences are aimed at exploiting all possible resources and potential as a fundamental factor for the development of the offshore economy. The maritime economy needs a dynamic and stochastic logis- tic system that will encompass other logistic phenomena without which the development of the maritime economy is not possible.

It is assumed that oil production will have its peak in the near future and by 2050 all supplies will be in deficiency. However, the lifespan of fossil fuels, especially oil, is difficult to forecast, as new hydrocarbon reserves are discovered at the same time and consumption is rationalized because of the advanced technology and more careful use due to high prices. The increased demand, on the other hand, happens due to the rapid industrialization of China and India, as well as to the high energy consumption in the US, which will be ranked fourth in the future. The direct growth rates of the variables predict that the Middle East will continue to be the world's leading force in oil imports and exports by $17.6 \%$, while Russia will achieve less than $5 \%$. It can be concluded that only a powerful logistic network of the maritime economy can ensure successful coping with the challenges of market economy and globalization.

\section{References}

[1] Bulić, A.: Prikaz stanja i projekcija razvoja sustava pomorskog gospodarstva, Zbornik radova Pomorskog fakulteta Rijeka, 7/2 1993.

[2] Dundović, Č.: Pomorski sustav i pomorska politika, Pomorski fakultet u Rijeci, Rijeka, 2003.

[3] Hrvatski opći leksikon, Leksikografski zavod Miroslav Krleža, Zagreb, 1996.

[4] Mrnjavac, E.: Pomorski sustav, Pomorski fakultet Rijeka, 1998.

[5] Šamanović, J.: Logistički i distribucijski sustavi, Ekonomski fakultet Sveučilišta u Splitu, Split.

[6] Tosenberger, A., Todorović, B.: Nafta i plin u Hrvatskoj, Rijeka, Geografski horizont, god.46, 2000, str. 67-77.

[7] Zelenika, R.: Logistički sustavi, Sveučilište u Rijeci, Rijeka 2004.

[8] Zelenika, R.: Prometni sustavi-Tehnologija-OrganizacijaEkonomika-Logistika Menadžment, Ekonomski fakultet Sveučilišta u Rijeci, Rijeka 2002.

[9] https: / / www.eia.gov/todayinenergy / detail. php?id=28552\#, $6^{\text {th }}$ July 2017.

[10] https://www.infield.com/media-centre/articles/2015/ global-subsea-market-review, $7^{\text {th }}$ July 2017.

[11] http://www.bp.com/content/dam/bp/en/corporate/pdf/ energy-economics/statistical-review-2017/bp-statisticalreview-of-world-energy-2017-full-report.pdfl, $\quad 3^{\text {rd }} \quad$ July 2017.

[12] http://www.npd.no/en/Topics/Resource-accounts-and-analysis/, $3^{\text {rd }}$ July 2017.

[13] https://www.google.hr/\#q=bp+statistical+review+of+worl d+energy+2016, $1^{\text {st }}$ May 2017.

[14] https://www.bp.com/content/dam/bp/pdf/energy-economics/statistical-review-2016/bp-statistical-review-ofworld-energy-2016-full-report.pdf, 27 ${ }^{\text {th }}$ May 2017.

[15] http://www.offshore-mag.com/articles/2017/01/npd-foresees-steady-stream-of-norwegian-field-developments.html, $5^{\text {th }}$ July 2017. 